\title{
Milli mentalitetdə fərdi məlumatların yeri və onların mühafizəsi problemləri
}

\author{
Rasim Oliquliyev $^{1}$, Rasim Mahmudov ${ }^{2}$ \\ ${ }^{1,2}$ AMEA İnformasiya Texnologiyaları İnstitutu, Bak1, Azərbaycan \\ ${ }^{1}$ director@iit.science.az, ${ }^{2}$ pr@iit.science.az
}

\begin{abstract}
Xülasə - Məqalədə şəxsi həyat və fərdi məlumtların mahiyyətinə dair yanaşmalar şərh olunur. Azərbaycan mentalitetində həssas fərdi məlumatların yeri və onlarla bağlı problemlər analiz edilir. Bu problemlərin aradan qaldırılması üçün kompleks təkliflər irəli sürülür.
\end{abstract}

Açar sözlor- şoxsi həyat; fordi molumatlar; hossas molumatlar; milli mentalitet.

\section{GİRIŞ}

Fərdlər haqqında məlumatların toplanması və emalı prosesləri bəşəriyyətin bütün inkişaf mərhələlərində olmuşdur. Müasir dövrdə isə sürətlə inkişaf edən İKT, o cümlədən müxtəlif elektron dövlət sistemlərində elektron kommersiya, elektron ödəniş, çoxsaylı İnternet xidmətləri, çoxfunksiyalı smartfonlar, GPS sistemləri, smart televizorlar, Đşyaların İnterneti texnologiyaları, videomüşahidə sistemləri, biometrik texnologiyalar və s. hər bir fərd haqqında fasiləsiz olaraq böyük həcmdə informasiya toplamaq imkanlarını dəfələrlə artırır. Bu imkanlar da, öz növbəsində, fərdi məlumatlarla bağlı daha geniş məqsədlərin ortaya çıxmasına zəmin yaradır.

Azərbaycanda da informasiya texnologiyalarının sürətli inkişaf prosesi gedir, artıq İnternet infrastrukturu bütün ölkəni ohatə edir, əhalinin $80 \%$-i İnternet istifadəçisidir, mobil telefon abunəçilərinin sayı isə 11 milyona çatıb [1]. Ölkəmizdə insanların söz və İnternet azadlıqları yüksək səviyyədə təmin edilib. Vətəndaşlarımız müxtəlif sosial şəbəkələrdən, elektron ticarət, virtual təhsil və digər xidmətlərdən fəal şəkildə istifadə edirlər. Bütün bunlar ölkəmizdə fərdi məlumatların qorunması məsələsini də aktuallaşdırır.

Fərdi məlumatların mühafizəsi məsələsinə, bütövlükdə, milli təhlükəsizlik prizmasından yanaşmaq lazımdır. Azərbaycanda tarixən milli və dini dəyərlərdən qaynaqlanan möhkəm ailə institutu mövcuddur. Bizim cəmiyyətdə ailə həyatına dair, xüsusən, zərif cinsin nümayəndələri ilə bağlı fərdi məlumatlara qarşı xüsusi həssaslıq mövcuddur. Ölkəmizdə ailə institutları dövlətimizin, cəmiyyətimizin təməli sayılır. Ona görə də dövlətimizin, cəmiyyətimizin təhlükəsizliyini təmin etmək üçün vətəndaşların bu tip məlumatları etibarlı şəkildə mühafizə edilməlidir. Çünki şəxsi həyata dair fərdi məlumatlara qanunsuz müdaxilələr ailələrin dağılmasına, psixoloji sarsıntılara və digər neqativ hallara səbəb ola bilər.

\section{II. ŞӘXSİ HӘYAT VӘ FӘRDİ MӘLUMATLARIN MAHIYYӘTINO DAİR YANAŞMALAR}

Fərdi məlumatlar şəxsi həyatın mühüm tərkib hissəsi sayılır. Başqa sözlə, şəxsi həyatın toxunulmazlığının təmin edilməsi həm də fərdi məlumatların mühafizəsini zəruri edir. Ona görə də fərdi məlumatların mahiyyətini daha aydın şəkildə təsəvvür etmək üçün ona şəxsi həyat prizmasından yanaşmaq məqsədəuyğundur.

"İnsan hüquqlarının və azadlıqlarının mühafizəsi haqqında" Avropa Konvensiyasının (1950) 8-ci maddəsininin tətbiq edilməsi praktikası sayəsində bu terminin dəqiq normativ izahı verilmişdir. Belə ki, Avropa İnsan Hüquqları Məhkəməsinin (1992) bəyanatında göstərilir: "Şəxsi həyat - tam təsvir edilə bilməyən geniş kateqoriyadır. Hər bir insan bu anlayışı inkişaf etdirməkdə və ona müəyyən məna verməkdə sərbəstdir. Bu anlayışı "daxili çevrə" ilə məhdudlaşdırmaq və bu çevrəyə daxil olmayan xarici aləmi istisna etmək yolverilməzdir. Beləliklə, "şəxsi həyat" anlayışı digər şəxslərlə və xarici aləmlə qarşılıqlı əlaqənin inkişaf etdirilməsi hüququnun zəruriliyini özündə əks etdirir" [2].

Şəxsi həyatın "toxunulmazlığı" anlayışının və beynəlxalq sənədlərdə işlədilən "privacy" termininin ümumi ekvivalenti azadlıq, məhrəmlik, sirr, tənhalıq, mülkiyyət, şəxsilik, özəllik, özəl yaşayış, toxunulmazlıq, şəxsiyyət, şəxsiyyətlərarası münasibətlər mənalarında işlədilən latın dilindəki "gizlilik" ifadəsidir. [3]:

Müasir ingilis dilində "privacy" aşağıdakı kimi şərh olunur

1. fərdi, şəxsi, sirli;

2. hamı üçün deyil, ayrıca bir insan, seçilmiş qrup üçün müəyyən edilmiş və ya nəzərdə tutulmuş;

3. müstəqil, hakimiyyətdən və dövlət xidmətindən asılı olmayan;

4. qeyri-rəsmi, rəsmi mövqe ilə bağlı olmayan, ictimai həyatdan asılı olmayan;

5. başqalarının görmədiyi, eşitmədiyi və nəzarət etmədiyi elə bir yer ki, oraya getmək mümkün olsun;

6. şəxsi həyatını yaşayan insan.

"Privacy" anlayışı rus dilində olan "Böyük hüquqi lüğət"də belə izah olunur [4]: “ingilis-amerikan hüquq sistemində şəxsi 


\section{“Informasiya tohlükosizliyinin aktual multidissiplinar elmi-praktiki problemlori” \\ V respublika konfransı, 29 noyabr 2019-cu il}

həyat sirrini və toxunulmazlığını, insanın intim sferasını ifadə edən xüsusi hüquqi kateqoriyadır. "Privacy" termininin rus dilində analoqu yoxdur. Bu termin bəzi hallarda "şəxsi həyat", digər hallarda "şəxsi həyat hüququ", başqa hallarda isə "şəxsi həyatın toxunulmazlığı hüququ" kimi anlaşıla bilər.

Azərbaycan dilində isə "privacy" termininin hələlik rəsmi olaraq nə elmi, nə də hüquqi izahı verilməmişdir.

Ümumi "məlumatlar" anlayışından xüsusi "fərdi məlumatlar" kateqoriyasının fərqləndirilməsi onunla əlaqədardır ki, bu cür məlumatlar insanın şəxsi həyatının həssas atributları sferasına aiddir. Bir sıra ölkələrin hüquqi sənədlərində bu cür məlumatları təsvir etmək məqsədi ilə "şəxsiyyəti identifikasiya etmək üçün informasiya" ifadəsindən istifadə edilir.

Fərdi məlumatları onların aid olduğu şəxslərin özlərinin münasibətinə görə iki kateqoriyaya ayırmaq olar [5]:

- açıqlanmasına və yayılmasına məlumat subyektlərinin etinasız yanaşdığ 1 "neytral" fərdiləşdirilmiş məlumatlar;

- subyektin dövriyyəsini məhdudlaşdırmaq istədiyi məlumatlar.

İkinci kateqoriyaya aid olanlar "fərdi məlumatlar" adlanır və bu cür məlumatın icazəsiz əldə edilməsi və istifadəsi beynəlxalq hüquqda "məlumat subyektinin hüquqlarına qəsd" kimi təsnif edilir.

Heç bir qanunvericilik aktinda fərdi məlumatların dəqiq siyahıs1 və ya sərhədi müəyyən edilməyib. O cümlədən, Azərbaycan qanunvericiliyinə görə, "fərdi məlumatlar - şəxsin kimliyini birbaşa və ya dolayısı ilə müəyyənləşdirməyə imkan verən istənilən məlumatlardır"'[6]. Bu cür məlumatların müəyyən edilməsinin özü də fərdi yanaşmadan asılıdır.

\section{AZӘRBAYCAN MENTALITETINDӘ HəSSAS FORDİ MOLUMATLARIN YERI VӘ YARATDIĞI PROBLEMLOR}

Doğrudur, şəxsi həyat və onun tərkib hissəsi olan fərdi məlumatların hüdudlarının müəyyən edilməsini nəzərdə tutan bir sira beynəlxalq və milli səviyyələrdə normativ-hüquqi sənədlər mövcuddur. Amma bu hüdudların müəyyən edilməsinin şəxsi, milli və regional ölçüləri də mövcuddur. $\mathrm{Bu}$ ölçülər heç də həmişə hüquqi çərçivələrlə üst-üstə düşmür. Bir çox hallarda müvafiq milli qanunvericilik aktları mental xüsusiyyətləri deyil, beynəlxalq tövsiyələri və xarici ölkələrin praktikasını nəzərə alaraq hazırlanır. Nəticədə fərdi məlumatlarla bağlı ictimai münasibətlərin tənzimlənməsi idarəolunmaz hala gəlib çıxır.

Azərbaycan da şəxsi həyata, fərdi məlumatlara münasibətdə mental dəyərlərin böyük təsir imkanına malik olduğu ölkələr sırasındadır. Ölkəmizdə şəxslərə aid həssas məlumatların əhatə dairəsi kifayət qədər genişdir. Zərif cinsin nümayəndələri ilə bağlı həssaslıq dərəcəsi isə daha yüksək həddədir (Onların yaş həddindən və ailə vəziyyətindən asılı olaraq həssaslıq səviyyəşi artıb-azalır). Bu da fərdi məlumatlarla bağlı şantaj və digər manipulyasiya hallarını stimullaşdıran amil kimi çıxış edir. Azərbaycanda İnternet istifadəçilərinin sayının yüksək həddə çatması, sosial şəbəkələrin əhali arasında yüksək populyarlıq qazanması nəticəsində fərdi məlumatların bədniyyətli əməllər üçün istifadə hallarının artması müşahidə olunur [5].

Bir sıra ölkələrdə qanunsuz əldə edilən fərdi məlumatlar biznes fəaliyyəti üçün dəyərli hesab olunur. Lakin elə ölkələr də var ki, orada bu cür məlumatlardan daha çox kriminal məqsədlər, o cümlədən şantaj məqsədi ilə istifadə edirlər. Araşdırmalarımız göstərir ki, Azərbaycanda da fərdi məlumatlardan aid olduğu şəxsləri şantaj etməklə olardan pul tələb etmək üçün istifadə halları az deyil. Ölkəmizdə şantaj məqsədi ilə daha çox qadınlara məxsus həssas fərdi məlumatlardan istifadə edilir. Azərbaycanda xanımlara aid fərdi məlumatların həssaslıq dərəcəsinin yüksək olması, ilk növbədə, milli-mənəvi dəyərlərdən irəli gəlir. Yəni bizim bu dəyərlərimizdə qadın adının çox yüksək tutulması ilə əlaqədardir.

Bir sıra hallarda isə müəyyən şəxsləri nüfuzdan salmaq, karyerasına zərbə vurmaq, ailəsində problem yaratmaq və s. neqativ məqsədlərlə onlar haqqında şəxsi həyata dair yanlış, yalan məlumatlar yayılır. Sürətlə inkişaf edən informasiya texnologiyaları da dezinformasiya xarakterli montaj edilmiş audio, video, foto materialları yaymağa imkan verir.

Ölkəmizin kütləvi informasiya vasitələrində vətəndaşların fərdi məlumatlarının qanunsuz açıqlanmasının neqativ nəticləri ilə əlaqədar xəbərlərə tez-tez rast gəlmək mümkündür. Təəssüflər olsun ki, Azərbaycanda fərdi məlumatların qanunsuz olaraq açıqlanması ilə əlaqədar baş verən bu cür neqativ hallarla bağlı tədqiqatlar aparılmır, müvafiq statistik hesabatlar hazirlanmir.

Fərdi məlumatların əldə edilərək yayılmasının digər populyar üsulu etibardan sui-istifadə edərək sosial şəbəkələr və mobil telefonlar vasitəsi ilə reallaşdırılan şəxsi yazışmaların mətnlərinin, audio-video söhbətlərin yazılarının, hətta şəxsi görüşlərin görüntülərinin tərəflərdən biri tərəfindən yaddaşa köçürülərək sonradan şantaj yolu ilə, hədə-qorxu ilə nəyisə tələb etmək üçün istifadə edilməsidir. Bu halda vəzifəli şəxs karyerasına zərbə vurulmasından, evli şəxs ailəsinin dağılmasından qorxaraq şantaj edənin tələblərini yerinə yetirməyə məcbur olur.

Azərbaycanda kafe və restoranlarda şəxsi kabinetlərə, avtomobillərdə jalüz və pərdəllərə, hündür hasarlı fərdi evlərə, villalara yüksək tələbatın olması da məhz başqalarının şəxsi həyatına yüksək marağın olması, zərif cinsin nümayəndələrinə aid fərdi məlumatların həssaslıq dərəcəsinin yüksək olması, insanların fərdi məlumatlar vasitəsi ilə şantaj edilmə riskinin yuxarı olması ilə əlaqədardır.

Doğrudur, Azərbaycan qanunvericiliyinə 2017-ci ildə edilmiş əlavə və dəyişikliklər İnternet mühitində fərdi məlumatların qanunsuz dövriyyəsinin qarşısının alınmasına xidmət edir, amma bu məsələ ilə bağlı ölkəmizdə məhkəmə praktikası çox zəifdir, müvafiq hüquqları pozulanlar tərəfindən məhkəmələrə müraciət etmə hallarına çox nadir hallarda rast gəlinir [7]. $\mathrm{Bu}$ sahədə vətəndaşlar arasında hüquq mədəniyyətinin formalaşmaması əsas səbəblərdən biridir. Vətəndaşlar hüquqlarını pozanların, onları təhdid edənlərin cəzalandırılmasını, onlara dəyən maddi və mənəvi ziyanın 


\section{“Informasiya tohlükosizliyinin aktual multidissiplinar elmi-praktiki problemlori” \\ V respublika konfransı, 29 noyabr 2019-cu il}

əvəzinin ödənilməsini tələb etməyə o qədər də meylli deyillər. Onlar daha çox hədəflərinə tuş gəldikləri ilə "dil tapmağa", məsələnin ictimailəşməsinin qarşısını almağa meyl göstərirlər.

Şəxsi həyatın toxunulmazlığının təmin olunması, fərdi məlumatların qorunması məsələləri müasir dövrdə informasiya texnologiyaları ilə sıx bağlıdır. Ona görə də bu sahədə texnoloji və hüquqi bilikləri özündə birləşdirən spesifik kadrların yetişdirilməsi vacibdir. Bu sahədə məhkəmə ekspertizasının obyektiv və effektli şəkildə həyata keçirilməsi üçün xüsusi laboratoriyaların təşkil edilməsinə ehtiyac vardır. Həqiqi və saxta foto, video görüntüləri, audio yazıları bir-birindən ayırmaq üçün xüsusi avadanlıqlar, biliklər və səriştə tələb edilir.

Müasir dövrün reallıqlarından biri də budur ki, bəzən insanların özləri fərdi məlumatlarını yaymaqda maraqlı olurlar. $\mathrm{Bu}$, əsasən, cəmiyyətdə neqativ populyarlıq qazanmaqla əldə etdikləri sosial kapitalı maddi kapitala çevirmək istəyənlərin tətbiq etdikləri bir üsuldur. Dünya şou-biznes aləmində bu usuldan geniş istifadə edilir. Son zamanlar Azərbaycanda da bu üsuldan istifadə halları müşahidə edilməkdədir.

Şəxsi həyat sirrinin, fərdi məlumatların qanunsuz olaraq yayılması yuxarıda qeyd edilən bir sıra problemlərə yol açdığı kimi, bəzən əksinə, onların gizli saxlanması müəyyən problemlər yaradır. $\mathrm{Bu}$ problemlər, əsasən, gənclərin ailə qurmaları ilə əlaqədardır. Məlum olduğu kimi, fərdi məlumatların ən mühüm əhəmiyyət kəsb edən növlərindən biri tibbi molumatlardır.

Tədqiqatlar göstərir ki, bir çox insanlar öz tibbi məlumatlarına daha həssas yanaşırlar, onları qorumaqda daha çox maraqlidırlar. Məsələn, informasiyanın mühafizəsi məsələlərinə böyük diqqət yetirən $E M C$ korporasiyası 2014-cü ildə fərdi məlumatlarının konfidensiallığına riayət edilməsinə dair insanların münasibətlərini analiz edən tədqiqatlarının nəticələrini dərc etmişdir [8]. Ümumilikdə, tibbi xidmət istifadəçilərinin fərdi məlumatlarının konfidensiallığının daha çox qayğısına qaldığı məlum olmuşdur.

$\mathrm{Bu}$, əsasən, onunla əlaqədardır ki, insanlar özlərinin səhhətləri, müəyyən xəstəlikləri ilə bağlı məlumatların açıqlanmasının peşə faəliyyətləri, karyeraları, eləcə də, ailə həyatı ilə bağlı problemlər yaratmasından narahat olurlar. Doğrudur, elə spesifik peşə fəaliyyəti sahələri var ki, işə qəbul zamanı müəyyən parametrlər üzrə sağlamlıq haqqında tibbi arayış tələb olunur. Lakin tibbi arayış tələb olunmayan sahələrdə də hər hansı şəxsin səhhəti ilə bağlı neqativ məlumatların yayılması onun peşə vəzifələrini lazımi səviyyədə yerinə yetirə bilməsinə dair inamsızlıq yarada bilər.

Azərbaycan reallığında fərdi tibbi məlumatlara daha çox ailə həyatının qurulması baxımından böyük həssaslıqla yanaşılır. Müəyyən neqativ tibbi göstəriciləri olan şəxslər ailə qurarkən bunu gizli saxlamağa nə qədər ciddi səy göstərirlərsə də, əks tərəf də bu cür məlumatların əldə edilməsində o qədər maraqlı olur. Adətən, ailə qurmaq istəyən gənclərin yaxınları və ya özləri əks tərəf haqqında müxtəlif fərdi məlumatları əldə etməyə çalışırlar. Bir çox hallarda ailə qurmaq haqqında qərar da bu məlumatların analizi əsasında verilir. Həmin məlumatların arasında ən yüksək həssaslıq dərəcəsinə malik olan da məhz tibbi məlumatlardır. O cümlədən genetik tibbi məlumatlar da qərar qəbuletmə üçün çox mühüm əhəmiyyət daşıyır [5].

Azərbaycanın 1 iyun 2015-ci il tarixindən tətbiq edilən mövcud qanunvericiliyinə əsasən, rəsmi nigaha girmək istəyən gənclər bunun üçün, ilk növbədə, tibbi müayinədən keçməlidirlər [9]. Doğrudur, tibbi müayinənin neqativ nəticələri olarsa, cütlüklərin evlənməməsinə dair yalnız tövsiyə verilir, yəni onlara ailə qurmaq qadağan edilmir. Amma bu cür tibbi müayinənin neqativ nəticəslərini əsas götürərək ailə qurmaqdan imtina edən gənclər də az deyildir.

Nəzərə almaq lazımdır ki, ölkəmizdə ailə qurmaq isəyən cütlüklər bu müayinədən, adətən, toy ərəfəsində keçirlər. Buna qədər elçilik, nişan, xınayaxdı kimi proseslərdən keçmiş, hətta qızın cehizini oğlan evində yerləşdirmiş, toy gününü və toyun keçiriləcəyi şadlıq evini müəyyənləşdirmiş, qonaqlara dəvətnamələr göndərmiş olurlar. Ona görə də son anda evlənməkdən imtina edilməsi böyük maddi və mənəvi-psixoloji problemlər yaradır.

Müvafiq tibbi müayinə zamanı iki qrup - genetik və infeksion xəstəliklər yoxlanılır. İnfeksion xəstəliklərlə bağlı tibbi arayış verildiyi vaxtdan bir ay müddətində etibarlı sayılır. Amma insanlara aid genetik məlumatlar dəyişməzdir. Ona görə də genetik uyğunluq haqqında məlumatları gənclər bir-birləri ilə münasibət qurmadan öncə də əldə edə bilərlər.

\section{AZORBAYCANDA FORDİ MOLUMATLARIN MÜHAFIZəSİ MəSӘLӘLӘRINO DAİR TOKLİFLOR}

İnformasiya texnologiyalarının sürətli inkişafı nəticəsində fərdi məlumatların əldə edilməsi imkanlarının hədsiz dərəcədə artması bu sahədə ictimai münasibətləri daha da mürəkkəbləşdirir və aktuallaşdırır. Doğrudur, bütün dünyada, eləcə də, Azərbaycanda bu münasibətləri daha effektli şəkildə tənzimləmək üçün vaxtaşırı qanunvericilik bazası təkmilləşdirilir, inkişaf etdirilir.

Lakin informasiya texnologiyalarının inkişaf tempi, o cümlədən 4-cü sənaye inqilabının yaratdığı yeni virtual reallıqlar və əhalinin həyat tərzinin buna uyğunlaşması fonunda dərin kök atmış mental dəyərləri qorumaq cəhdlərinin doğurduğu situasiyanı yalnız qanunvericilik çərçivəsində nizmlamaq mümkün olmur. $\mathrm{Bu}$ məsələni yalnız hüquqi müstəvidə həll etmək cəhdləri yetərsizdir. Məsələnin uğurlu həlli, ilk növbədə, kompleks baxış bucaqlarının bir araya gətirildiyi multidistiplinar elmi araşdırmaların aparılmasını tələb edir. Fərdi məlumatların mühafizəsi sahəsində hüquqi aspektlərlə yanaşı, texnoloji, sosial, psixoloji, kulturoloji, iqtisadi və s. istiqamətlər üzrə tədqiqatların aparılması aktuallıq kəsb edir. Halbuki bu gün fərdi məlumatlarla bağlı problemlər, bütövlükdə, dünya elmində daha çox hüquqi və qismən də texnoloji məsələ kimi qəbul olunur.

Fərdi məlumatların qorunması sahəsində texnoloji, hüquqi və s. zəruri biliklərə malik olan yüksəkixtisaslı kadrların hazırlanmasına ciddi ehtiyac vardır. Xüsusən, hüquq-mühafizə orqanlarında, məhkəmə-eksperiza sahəsində bu cür kadrların çatışmazlığı hiss olunur. Bu sahə üzrə, ilk növbədə, elmipedoqoji kadraların yetişdirilməsi vacibdir. Məhz bu sahə üzrə 


\section{“Informasiya tohlükosizliyinin aktual multidissiplinar elmi-praktiki problemlori” \\ V respublika konfransı, 29 noyabr 2019-cu il}

elmi-pedoqoji kadrlar olmalıdır ki, onların vasitəsi ilə digər müvafiq mütəxəssislər hazırlansin.

Fərdi məlumatlar və onların qorunması mexanizmləri haqqında vətəndaşlar çox cüzi və səthi məlumatlara malikdirlər. Ümumiyyətlə, ölkədə virtual və texnoloji hüquq mədəniyyəti çox zəifdir. Ona görə də əhali arasında, xüsusən, gənc nəslin nümayəndələrinə bu sahədə maarifləndirici tədbirlərin həyata keçirilməsi vacibdir. Bu gün Azərbaycan vətəndaşları sosial şəbəkələrdən və digər İnternet xidmətlərindən geniş istifadə edirlər ki, bu zaman fərdi məlumatlarla düzgün davranmaq tələb olunur. Hətta təhsil proqramlarına müvafiq dərslərin daxil edilməsi zəruridir.

Dünyanın bir sıra ölklərində vətəndaşların fərdi məlumatlarının qorunmasına cavabdeh olan rəsmi dövlət qurumları fəaliyyət göstərir. Məsələn, Avstraliyada "İnformasiya konfidensiallığı üzrə komissarlıq", Kanadada "İnformasiya hüquqları üzrə ombudsman", Almaniyada "İnformasiya azadlığı və məlumatların qorunması üzrə komissar", Hindistanda "Dövlət informasiya ombudsmanı", İsveçrədə "İnformasiyanın qorunması üzrə komissarlıq", Böyük Britaniyada "Fərdi məlumatların qorunmas1, informasiya azadlığı və informasiya ekologiyası üzrə ombudsman" adlı təsisatlar mövcuddur [10]. Həmin təsisatlar öz fəaliyyəti barədə illik hesabatlar verirlər.

"Informasiya əldə etmək haqqinda" Azərbaycan Respublikasıın Qanununda (2005) da ölkəmizdə “informasiya məsələləri üzrə müvəkkil" vəzifəsinin təsis edilməsi nəzərdə tutulmuşdu [11]. Lakin 2012-ci ildə bu qanuna edilən dəyişikliklərə uyğun olaraq, həmin vəzifəsinin icrası İnsan hüquqları üzrə Ombudsmana həvalə edilmişdir. Digər ölkələrdən fərqli olaraq, Azərbaycanın İnsan hüquqları üzrə Ombudsmanı ölkədəki informasiya hüquqlarının qorunması vəziyyəti ilə bağlı illik hesabatlar vermir. Yaxşı olardı ki, qabaqcil ölkələrdə olduğu kimi, Azərbaycanda da informasiya hüquqları üzrə ayrıca qurum fəaliyyət göstərsin, dövlət və cəmiyyət qarşısında hesabatlı olsun.

Ölkəmizdə fərdi məlumatların qeyri-qanuni ictimailəşdirilməsində elektron kütləvi informasiya vasitələri və sosial şəbəkə istifadəçiləri xüsusi rol oynayır. Jurnalistlərin fərdi məlumatlarla işləyərkən müvafiq hüquqi tələbləri yaxşı bilməmələri və nəzərə almamaları bu cür halların kütləviləşməsinə səbəb olur. Ona görə də jurnalistika təhsilinə dair proqramlara fərdi məlumatlarla bağlı dərslərin daxil edilməsi, həmçinin bu sahədə çalışanlar üçün mütəmadi olaraq müvafiq təlimlərin təşkil edilməsi zəruridir.

Həmçinin ölkədə sağlam nəslin yetişdirilməsi, ölkənin demoqrafik təhlükəsizliyi, ailələrdə problemlərin yaranmaması baxımından tibbi xarakterli müvafiq fərdi məlumatların maraqlı şəxslər üçün açıqlanmasının təmin edilməsi arzuolunan haldır. Lakin bu zaman insan hüquqlarına dair beynəlxalq normaların və onun əsasında formalaşdırılan milli qanunvericiliyin tələblərinin gözlənilməsi də vacib şərtdir.

\section{NəTİCə}

Müasir dövrdə əsas maddi sərvətə çevrilən informasiyanın mühüm bir hissəsi fərdi xarakterlidir, hansısa şəxslərə aiddir və onların taleyində mühüm rol oynayır. Fərdi məlumatların mühafizəsi həm də yaşadığımız informasiya cəmiyyətində təhlükəsizliyin, asayişin təmin edilməsinin, milli-mənəvi dəyərlərimizin qorunmasının mühüm vasitələrindən və istiqamətlərindən biridir. $\mathrm{Bu}$ baxımdan, fərdi məlumatların mühafizəsinə dövlətin strateji maraqları prizmasından yanaşılması vacibdir.

\section{ӘDӘВIYYAT}

[1] Azərbaycan Dövlət Statistika Komitəsi, İnformasiya və kommunikasiya kexnologiyaları (IKT) üzrə əsas göstəricilər, http://www.stat.gov.az

[2] О. Красотенко, Понятие «частная жизнь» в решениях Европейского Суда по правам человека, Сборник тезисов 68-й научнопрактической конференции студентов, магистрантов и аспирантов факультета международных отношений БГУ. Минск, 27 апреля 2011, с. 51-53.

[3] М. Мельников, О семантике понятия “приватное”, ХІІІ международная научная конференция преподавателей, аспирантов и студентов НСИ, 2012, с.181-189.

[4] А. Сухарев, В. Крутских, А. Сухарева, Большой юридический словарь., М.: Инфра-М., 2009, 858 с.

[5] R.Oliquliyev, R.Mahmudov, Milli mentalitet kontekstində fərdi məlumatların həssaslığı və onların təhlükəsizliyinin təmin edilməsi məsələləri, İnformasiya cəmiyyəti problemləri, 2019, №2, s. 117-128.

[6] "Fordi məlumatlar haqqında" Azərbaycan Respublikasının Qanunu, http://www.e-qanun.az/framework/19675

[7] "Informasiya, informasiyalaşdırma vo informasiyanın mühafizəsi haqqında" Azərbaycan Respublikasının Qanununda dəyișikliklər edilməsi barədə Azərbaycan Respublikasının Qanunu, http://eqanun.az/framework/35124

[8] В. Коржов, Менталитет и конфиденциальность // Открытые системы, 2014, https://www.osp.ru/news/articles/2014/24/13041843

[9] Nikaha daxil olanşəxslərin tibbi müayinəsi ilə bağlı "Azərbaycan Respublikasının Ailə Məcəlləsində dəyişikliklərin edilməsi haqqında"Azərbaycan Respublikası Prezidentinin 2014-cü il 15 dekabr tarixli 389 nömrəli Formanının icrası barədə Azərbaycan Respublikası Səhiyyə Nazirliyi Kollegiyasının Qərarı, 25 may 2015-ci il, http://www.sehiyye.gov.az/files/pdf/2015qerar26.pdf

[10] B.van der Sloot, S. van Schendel, International and comparative legal study on Big Data, The Netherlands Scientific Council for Government Policy, 2016, 126 p.

[11] "Informasiya əldə etmək haqqında" Azərbaycan Respublikasın Qanunu, http://www.e-qanun.az/framework/11142

\section{THE PLACE OF PERSONAL DATA IN THE NATIONAL MENTALITY AND ISSUES OF ITS PROTECTION}

Rasim Alguliyev $^{1}$, Rasim Mahmudov ${ }^{2}$

${ }^{1,2}$ Institute of Information Technology of ANAS, Baku, Azerbaijan

${ }^{1}$ r.alguliev@gmail.com, ${ }^{2}$ rasimmahmudov@gmail.com

Abstract - The article interprets the approaches to personal life and personal data. The place of sensitive personal data in the Azerbaijan mentality and related problems are identified. Complex proposals are offered to eliminate these problems.

Keywords - personal life, personal data, sensitive information, national mentality 